\title{
PENGARUH KOMBINASI PAKAN KOMERSIAL DENGAN DAUN KANGKUNG AIR (Ipomoea aquatica) TERHADAP PERTUMBUHAN BENIH IKAN MAS (Cyprinus carpio)
}

\section{THE EFFECT OF COMMERCIAL FEED COMBINATION WITH WATER SPINACH LEAVES (Ipomoea aquatica) ON THE GROWTH OF COMMON CRAP SEED (Cyprinus carpio)}

\author{
Sultan Hamdi Muhammad Tahir ${ }^{1 *}$, Ayu Adhita Damayanti ${ }^{1}$, Dewi Putri Lestari ${ }^{1}$ \\ ${ }^{1}$ Program Studi Budidaya Perairan, Fakultas Pertanian, Universitas Mataram \\ *Korespondensi: sulthanguru@gmail.com
}

\begin{abstract}
This study aimed to analyze the effect of commercial feed combination with water spinach leaves (Ipomoea aquatica) at different ratios on the growth of common carp (Cyprinus carpio). This research was conducted for 35 days, located in Seteluk Atas Village, Seteluk District, West Sumbawa Regency. The common carp seeds used were $5-7 \mathrm{~cm}$ in size from one brood. The container used was 16 liter in size with a density of 10 fish / treatment. The method used in this study was an experimental method using a completely randomized design (CRD) with five treatments and three replications, namely, P1: 100\% commercial feed (control), P2: commercial feed + water spinach leaves $(1+1)$, P3: commercial feed + water spinach leaves $(1+2)$, P4: commercial feed + water spinach leaves $(1+3), P 5$ : $100 \%$ water spinach leaves. The data obtained were then calculated and analyzed by using analysis of variance (ANOVA). The results of this study indicated that the use of commercial feed combination with water spinach leaves can affect growth, feed efficiency and feed conversion of common carp but did not affect the survival of common carp. Provision of $100 \%$ commercial feed (P1) and combination of commercial feed with water spinach leaves at a ratio of 1:2 (P3) had the same effect in increasing the growth of common carp, namely $1.17 \mathrm{~g}$ and $1.11 \mathrm{~g}$, respectively.
\end{abstract}

Keywords: Feed comparison, Ipomoea aquatica, Cyprinus carpio

\section{Pendahuluan}

Ikan mas (Cyprinus carpio) merupakan komoditas penting dalam budidaya perikanan air tawar. Sebagai ikan yang sudah lama di kenal dan di konsumsi masyarakat, ikan mas relatif mudah untuk dibudidayakan, dan permintaan masyarakat semakin meningkat. Menurut Putri (2016), Potensi areal budidaya air tawar di Nusa tenggara Barat (NTB) memiliki luas 9.129 ha dan tingkat pemanfaatan lahan baru mencapai $2.772,36$ ha $(30,37 \%)$. Produksi prikanan budidaya air tawar wilayah NTB tahun 2017 mencapai 50.700 ton salah satunya produksi dari Ikan Mas sebesar 2.360,75 ton (Dinas Kelautan dan Perikanan Provinsi NTB, 2017).

Salah satu penentu keberhasilan dalam kegiatan budidaya Ikan Mas adalah pakan. Benih Ikan Mas membutuhkan pakan yang dapat memenuhi semua kebutuhan nutrisi sehingga mendapatkan pertumbuhan yang optimal. Namun tingginya harga pakan komersil merupakan salah satu permasalahan utama bagi 
pembudidaya Ikan Mas. Pakan yang digunakan pada umumnya adalah pakan komersil yang dapat menghabiskan sekitar $60-70 \%$ dari dari total biaya produksi (Suryaningrum dan Maharani, 2014 dalam Haerudin et al., 2017). Untuk menekan harga pakan komersil (pellet) cukup mahal ini beberapa pembudidaya Ikan Mas cenderung menggunakan daun-daunan sebagai sumber pakan yang dapat diberikan bersama dengan pakan komersil untuk menurunkan harga pakan dalam budidaya ikan, antara lain kangkung, talas, singkong, ubi jalar, dan pepaya. Jenis-jenis daun ini relatif disukai ikan, misalnya Ikan Mas, gurame, dan tawes (Putra, 2017).

Penelitian ini menggunakan daun kangkung air (Ipomoea aquatic) sebagai salah satu kombinasi bahan pakan yang juga sering digunakan oleh petani ikan. Selain itu kangkung air mudah didapat dikarenakan budidaya yang mudah dan budidayanya tidak tergantung musim pada setiap wilayah khususnya pada pulau Lombok dan Sumbawa. Berdasarkan uraian di atas maka, perlu dilakukan penelitian mengenai pengaruh kombinasi pakan komersial dengan daun kangkung air (I. aquatica) pada berbagai perbandingan yang berbeda terhadap pertumbuhan Ikan Mas (C. carpio).

Penelitian ini bertujuan untuk menganalisis pengaruh kombinasi pakan komersial dengan daun kangkung air (Ipomoea aquatica) pada perbandingan yang berbeda terhadap pertumbuhan Ikan Mas (Cyprinus carpio).

\section{Metode Penelitian}

\section{Bahan dan Alat}

Bahan penelitian yang digunakan yaitu benih ikan MAS ukuran 5-7 cm, daun kangkung air, pakan komersial, air tawar, aquades dan sabun anti septik. Peralatan yang digunakan yaitu toples ukuran $16 \mathrm{~L}$, aerator, timbangan analitik dengan ketelitian 0,01 g, penggaris, kamera, $\mathrm{pH}$ meter, thermometer digital, DO meter, saringan, selang sipon, pisau dan talenan.

\section{Metode Penelitian}

Hewan uji yang digunakan yaitu Ikan Mas yang didapatkan dari pembudidaya di Desa Dalam Alas, Sumbawa dengan jumlah ikan sebanyak 150 ekor dengan panjang $5-7 \mathrm{~cm}$, masing-masing perlakuan berisi 10 ekor. Pakan yang digunakan dalam penelitian ini adalah Pakan komersial yang digunakan dalam penelitian ini adalah merk Hi Pro Vite 781-1 berupa pellet dengan kandungan protein kasar (crude protein) 31-33 \% yang umum digunakan pada kegiatan budidaya Ikan Mas. Sedangkan frekuensi pemberian pakan sebanyak 3 kali sehari pada pukul 08.00 WITA, 13.00 WITA dan 16.00 WITA. Penelitian ini menggunakan metode Rancangan Acak Lengkap (RAL) satu faktor dengan 5 perlakuan dan masing masing perlakuan memiliki 3 ulangan. Taraf perlakuan penelitian ini ialah :

P1 : Pakan Komersil 100\% (Kontrol)

P2 : Pakan Komersil + Daun kangkung Air (1 gram+1 gram)

P3 : Pakan Komersil + Daun kangkung Air (1 gram+2 gram)

P4 : Pakan Komersil + Daun kangkung Air (1gram +3 gram) 
P5 : Daun Kangkung Air 100\%

\section{Pemberian Pakan}

Pakan komersial yang digunakan dalam penelitian ini adalah merk Hi Pro Vite 781-1 berupa pellet dengan kandungan protein 31-33 \% yang umum digunakan pada kegiatan budidaya Ikan Mas. Kangkung yang digunakan adalah bagian daun yang masih muda dengan umur tanam yang sama. Daun kangkung air kemudian dicacah sampai berukuran sekitar $0,5 \mathrm{~cm}$ x $0,5 \mathrm{~cm}$. Pakan komersial kemudian dikombinasikan dengan daun kangkung air yang telah dicacah sesuai dengan perbandingan yang telah ditentukan pada setiap perlakuan.

\section{Analisa Data}

Data yang diperoleh diuji menggunakan Analysis of Variance (ANOVA) pada taraf kepercayaan 95\% melalui program SPSS untuk mengetahui pengaruh dari setiap perlakuan. Apabila hasil analisis statistik menunjukkan pengaruh yang berbeda nyata, maka dilakukan uji lanjut BNT untuk mengetahui perlakuan terbaik.

\section{Hasil dan Pembahasan}

\section{Pertumbuhan Berat dan Panjang Mutlak}

Hasil analisis sidik ragam menunjukan bahwa penggunaan kombinasi pakan komersial dengan daun kangkung berpengaruh nyata $(\mathrm{p}<0.05)$ terhadap pertumbuhan berat dan panjang mutlak Ikan Mas, sehingga dilakukan uji lanjut Tukey untuk mengetahui perlakuan terbaik. Hasil uji lanjut menunjukan bahwa Perlakuan P1 (pellet komersil 100\%) tidak berbeda nyata dengan perlakuan P3 (pellet: kangkung $=1: 2$ ), namun berbeda nyata dengan perlakuan P2 (pellet : kangkung $=1: 1)$, P4 (pellet $:$ kangkung $=1: 3)$ dan P5 (kangkung 100\%) (Gambar $1,2)$

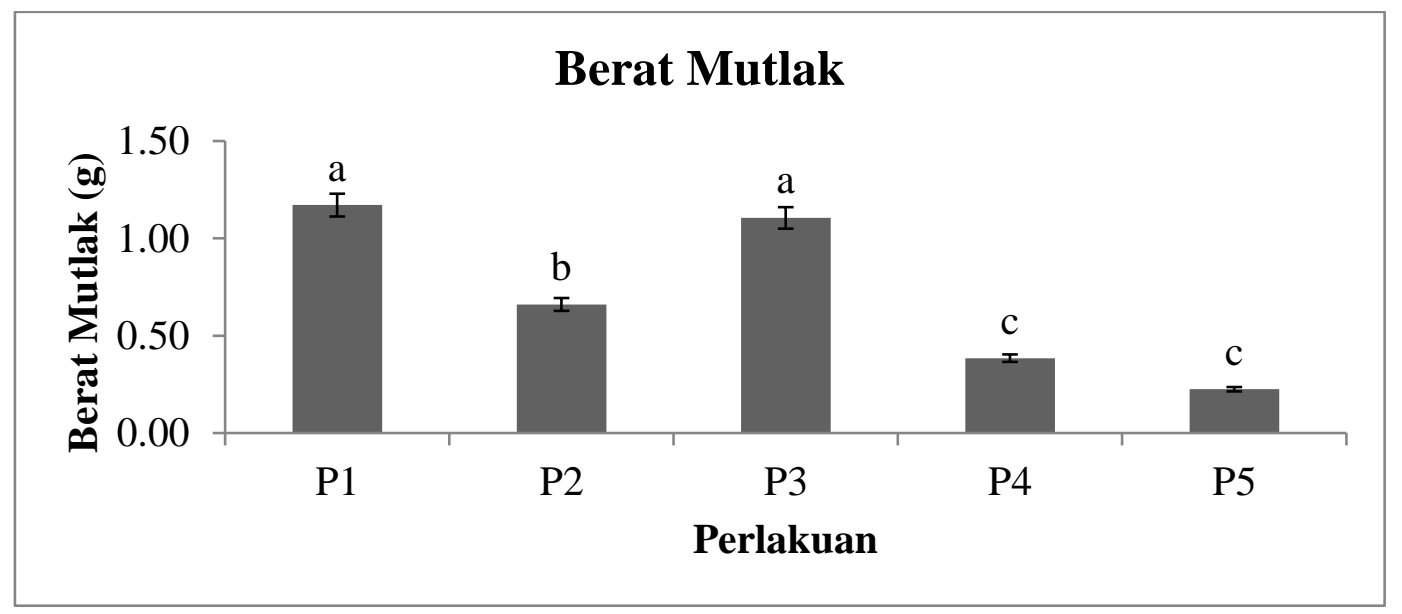

Gambar 1. Pertumbuhan Berat Mutlak Ikan Mas. 


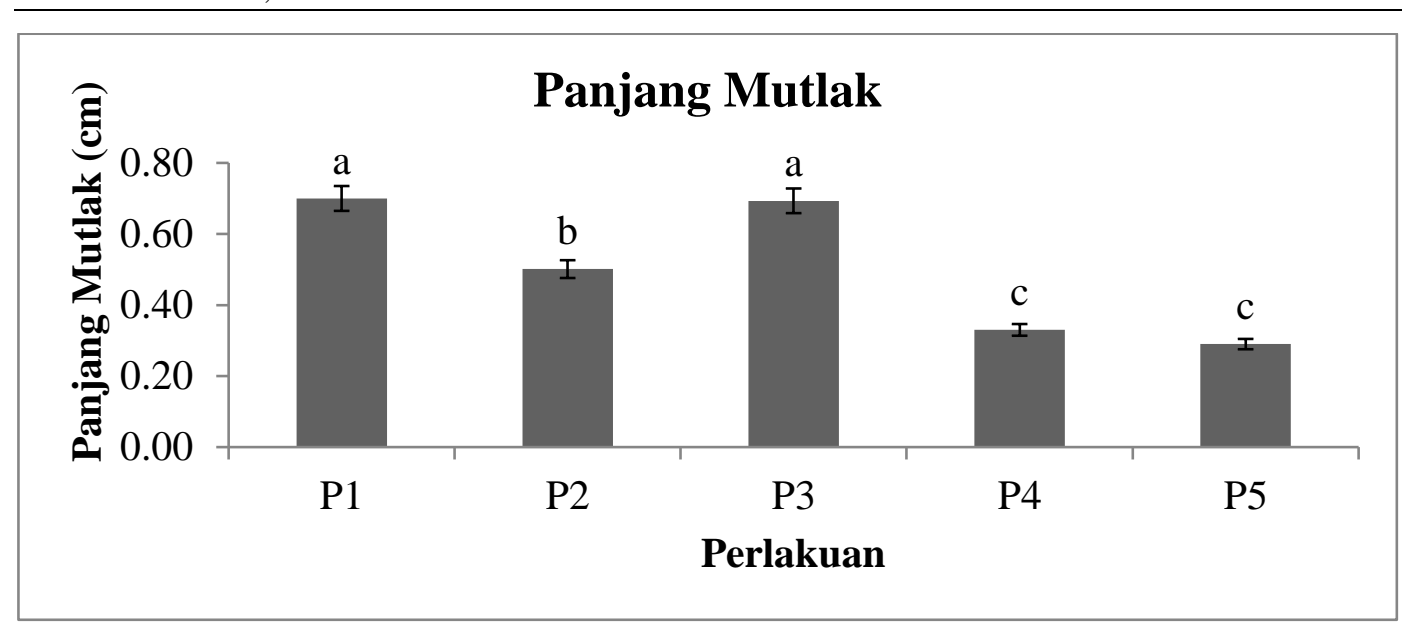

Gambar 2. Laju Pertumbuhan Panjang Mutlak Ikan Mas.

\section{Laju Pertumbuhan Spesifik}

Hasil analisis sidik ragam menunjukan bahwa penggunaan kombinasi pakan komersial dengan daun kangkung berpengaruh nyata $(\mathrm{p}<0.05)$ terhadap pertumbuhan berat spesifik Ikan Mas, sehingga dilakukan uji lanjut Tukey untuk mengetahui perlakuan terbaik. Hasil uji lanjut menunjukan bahwa Perlakuan P1 (pellet komersil 100\%) tidak berbeda nyata dengan perlakuan P3 (pellet : kangkung $=1: 2$ ), namun berbeda nyata dengan perlakuan P2 (pellet : kangkung $=1: 1$ ), P4 (pellet : kangkung = 1:3) dan P5 (kangkung 100\%) (Gambar 3).

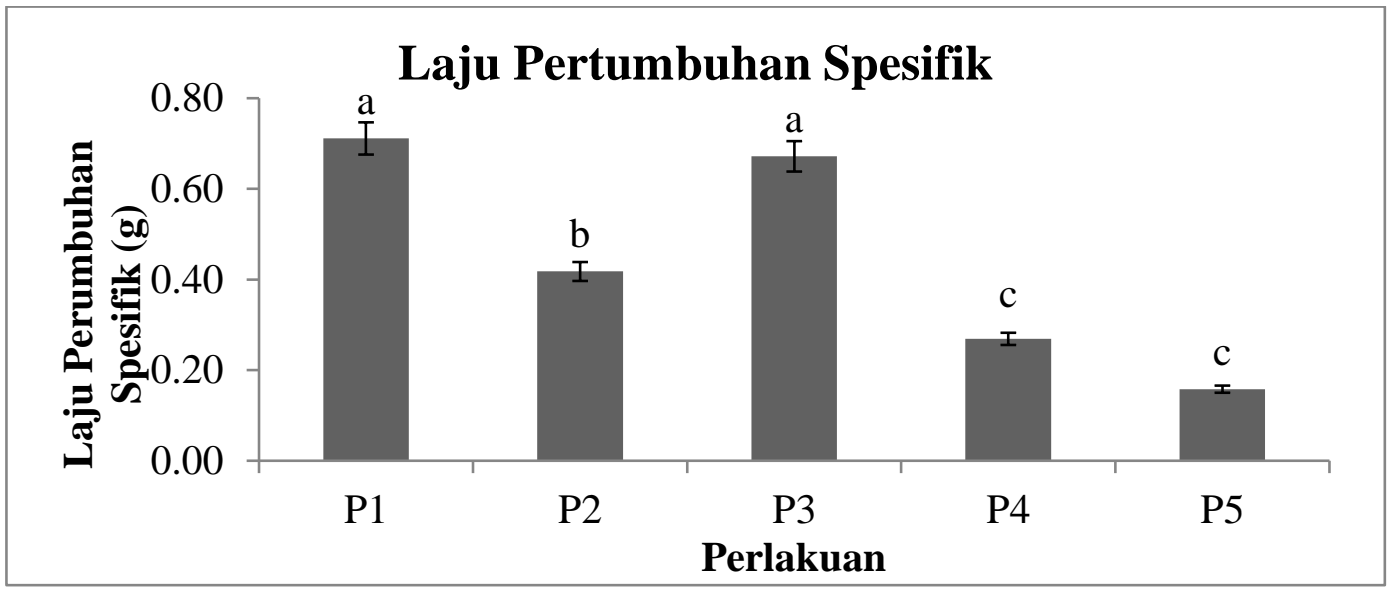

Gambar 3. Laju Pertumbuhan Berat Spesifik Ikan Mas.

\section{Efisiensi Pakan}

Hasil analisis sidik ragam menunjukan bahwa penggunaan kombinasi pakan komersial dengan daun kangkung berpengaruh nyata $(\mathrm{p}<0.05)$ terhadap nilai efesiensi pemanfaatan pakan, sehingga dilakukan uji lanjut Tukey untuk mengetahui perlakuan terbaik. Hasil uji lanjut menunjukan bahwa Perlakuan P1 (pellet komersil 100\%) tidak berbeda nyata dengan perlakuan P3 (pellet : kangkung = 1:2), namun berbeda nyata dengan perlakuan P2 (pellet : kangkung =1:1), P4 (pellet : kangkung = 1:3) dan P5 (kangkung 100\%) (Gambar 4). 


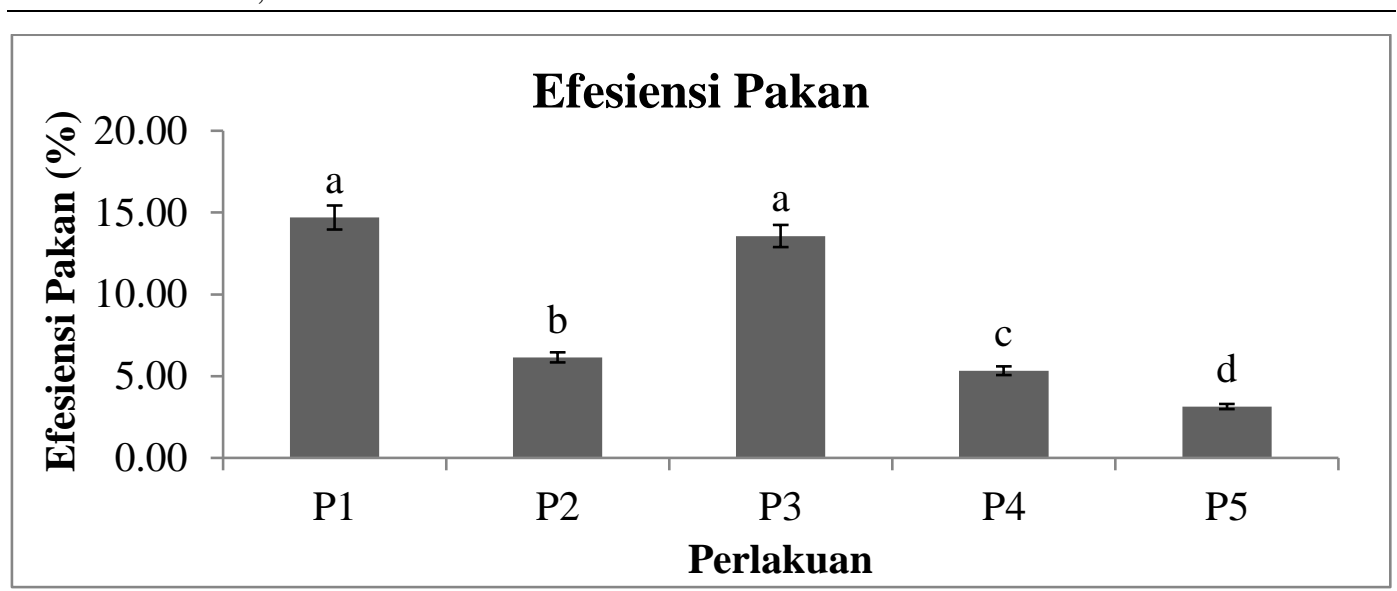

Gambar 4. Efisiensi Pakan Ikan Mas.

\section{Konversi Pakan}

Hasil analisis sidik ragam menunjukan bahwa penggunaan kombinasi pakan komersial dengan daun kangkung berpengaruh nyata $(\mathrm{p}<0.05)$ terhadap nilai konversi pakan, sehingga dilakukan uji lanjut Tukey untuk mengetahui perlakuan terbaik. Hasil uji lanjut menunjukan bahwa Perlakuan P1 (pellet komersil 100\%) tidak berbeda nyata dengan perlakuan P2 (pellet : kangkung = 1:1), P3 (pellet : kangkung $=1: 2$ ) dan P4 (pellet : kangkung = 1:3) namun berbeda nyata dengan perlakuan P5 (kangkung 100\%) (Gambar 5).

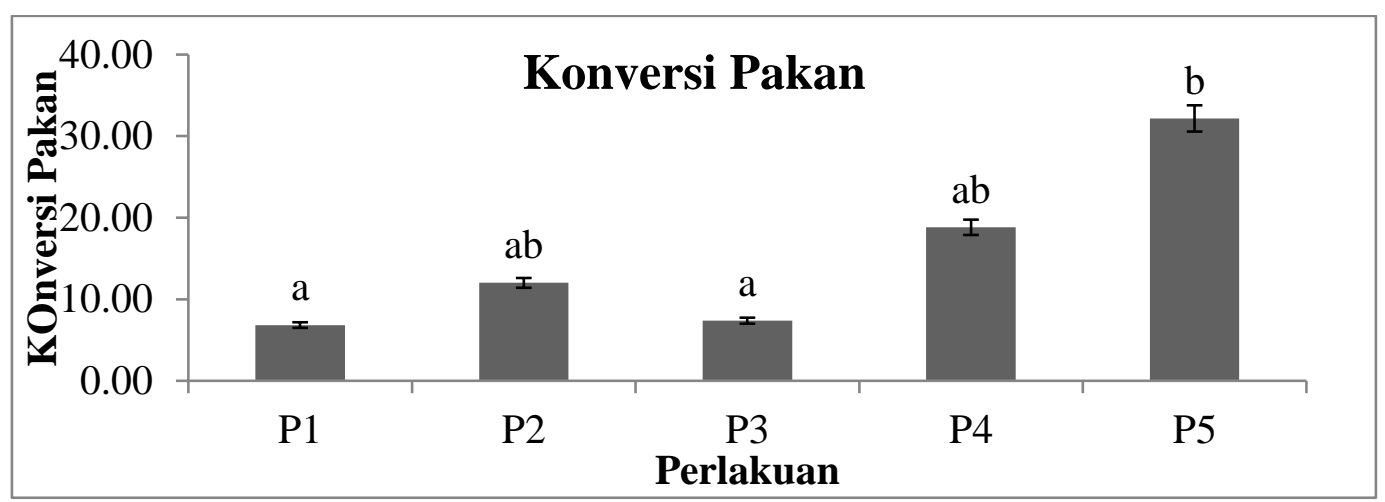

Gambar 5. Konversi Pakan Ikan Mas.

\section{Kelangsungan Hidup}

Hasil analisa tingkat kelangsungan hidup Ikan Mas dari awal tebar sampai akhir pemeliharaan menunjukkan hasil yang tidak berbeda nyata $(\mathrm{p}>0,05)$, dimana tingkat kelagsungan hidupnya tinggi diatas 90\%. Data nilai kelangsungan hidup Ikan Mas disajikan dalam bentuk persentase (Tabel 1). 
Tabel 1. Kelangsungan Hidup Ikan Mas.

\begin{tabular}{ccc}
\hline Perlakuan & $\begin{array}{c}\text { Tingkat kelangsungan hidup / } \\
\text { SR }(\%)\end{array}$ & Keterangan \\
\hline P1 & 97,50 & Mati 1 hari ke-30 \\
P2 & 97,50 & Mati 1 hari ke-31 \\
P3 & 100 & - \\
P4 & 100 & - \\
P5 & 100 & - \\
\hline
\end{tabular}

Keterangan : $\mathrm{P} 1=$ pakan komersial $(100 \%) ; \mathrm{P} 2=$ pakan komersil $:$ daun kangkung air $(1: 1) ; \mathrm{P} 3=$ pakan komersil : daun kangkung air (1:2) ; P4= pakan komersil : daun kangkung air (1:3); P5= daun kangkung air (100\%).

Berdasarkan Tabel 1, pada semua perlakuan diperoleh angka kelangsungan hidup Ikan Mas berkisar antara 97,50 - 100\%. Hasil analisis sidik ragam menunjukkan bahwa tidak terdapat perbedaan yang nyata terhadap kelangsungan hidup Ikan Mas pada berbagai perlakuan kombinasi pakan komersial dengan daun kangkung. Angka kelangsungan hidup Ikan Mas tertinggi terdapat pada perlakuan P3 (pellet : kangkung $=1: 2$ ), P4 (pellet : kangkung $=1: 3$ ) dan perlakuan P5 (kangkung $100 \%$ ) yaitu sebesar $100 \%$, sedangkan angka kelangsungan hidup pada perlakuan P1 (pellet 100\%) dan P2 (pellet : kangkung $=1: 1$ ) memiliki nilai kelangsungan hidup yang sama sebesar $97,50 \%$.

\section{Kualitas Air}

Hasil pengamatan kualitas air selama 35 hari pemeliharaan yang dilakukan diperoleh nilai kisaran suhu, $\mathrm{pH}$ dan $\mathrm{DO}$ terdapat dalam batas kelayakan pemeliharaan Ikan Mas. Kualitas air mempunyai peranan penting sebagai pendukung kehidupan dan pertumbuhan benih Ikan Mas. Data pengukuran kualitas air selama penelitian disajikan pada Tabel 2. Data yang ditampilkan merupakan data kisaran kualitas air pada semua perlakuan selama penelitian.

Tabel 2. Data Nilai Kualitas Air Selama Penelitian

\begin{tabular}{llll}
\hline Parameter & Satuan & Hasil & Pustaka kelayakan \\
\hline Suhu & ${ }^{\circ} \mathrm{C}$ & $27,5-29$ & $27-31$ (SNI, 2012) \\
pH & - & $7,5-8$ & $7,0-8,5$ (Fitrianingsih, et al.,2013) \\
DO & $\mathrm{mg} / \mathrm{l}$ & $3,8-5,5$ & min. 3 mg/l (SNI, 2012) \\
\hline
\end{tabular}

\section{Pembahasan}

Hasil penelitian ini menunjukan bahwa secara keseluruhan perlakuan pakan komersial $100 \%$ (P1) dan perlakuan kombinasi pakan komersial dengan daun kangkung air pada perbandingan 1:2 (P3) memberikan pengaruh yang sama baiknya terhadap peningkatan pertumbuhan mutlak dan spesifik Ikan Mas baik untuk berat maupun panjangnya (Gambar 1, 2, dan 3). Perlakuan pakan komersial $100 \%$ (P1) merupakan pakan yang sudah umum digunakan sebagai pakan ikan karena mempunyai aroma yang disukai ikan dan memiliki kandungan nutrisi yang 
baik dan sudah disesuaikan dengan kebutuhan ikan sehingga dapat mempercepat laju pertumbuhan Ikan Mas dengan optimal. Menurut Ciptanto (2010) dalam Putra (2017), pertumbuhan ikan dipengaruhi oleh nafsu makan ikan yang juga dipengaruhi oleh ruang gerak ikan serta pada kandungan pakan tersebut. Pakan ikan harus mengandung protein, lemak, karbohidrat, vitamin dan mineral dalam jumlah yang cukup untuk memenuhi kebutuhan untuk pertumbuhan dan perkembangan.

Hal yang sama juga ditunjukan pada perlakuan kombinasi pakan komersil dengan daun kangkung air pada perbandingan 1:2 (P3). Walaupun diberikan tambahan daun kangkung air dua kali lipat dari pakan komersial tetapi ikan masih memberikan respon adaptasi yang baik terhadap kombinasi pakan tersebut. Dugaan ini didukung oleh hasil pengamatan secara visual di lapangan, dimana tidak ditemukan adanya sisa pakan baik pakan komersial maupun daun kangkung air yang tersisa pada media pemeliharaan. Disamping itu pemberian daun kangkung air dengan perbandingan dua kali lipat dari pakan komersial masih dapat melengkapi dan memenuhi kebutuhan nutrient pada pakan komersial yang jumlahnya berkurang pada perlakuan P3 tersebut. Menurut Yunaidi et al., (2019), pakan ikan harus memiliki nutrisi yang cukup, mudah dicerna oleh ikan, tidak mengandung zat-zat berbahaya bagi ikan dan memiliki jumlah yang cukup untuk memenuhi kebutuhan untuk pertumbuhan dan perkembangan. Yanuar (2017), menyatakan bahwa daun kangkung air merupakan salah satu pakan tambahan yang dapat membantu mempercepat pertumbuhan ikan. Setiap $100 \mathrm{~g}$ daun kangkung air memiliki kandungan gizi yang terdiri atas protein sebesar $3 \mathrm{~g}$, vitamin A $470 \mathrm{mg}$, vitamin B1 0,07 mg, vitamin C $32 \mathrm{mg}$, kalsium $73 \mathrm{mg}$, karbohidrat 5,4 g, energi 29 kal dan kadar serat $1 \mathrm{~g}$.

Walaupun daun kangkung air memiliki kandungan serat kasar yang cukup tinggi, namun pada perlakuan P3 tersebut pemberian daun kangkung air diduga masih dalam jumlah yang bisa ditoleransi untuk dicerna oleh saluran pencernaan Ikan Mas sehingga dapat dimanfaatkan untuk pertumbuhan dan melakukan pergerakan. Hal ini menyebabkan sehingga perlakuan P3 mempunyai pengaruh yang sama dengan perlakuan P1 terhadap pertumbuhan mutlak dan spesifik Ikan Mas, baik untuk berat maupun panjangnya. Kondisi ini sangat didukung oleh fisiologis Ikan Mas yang tergolong ikan herbivora dan memiliki usus yang panjang dimana terdapat enzim yang digunakan untuk mencerna makanan dengan kandungan serat tinggi. Menurut Uthamy (2012), keadaan usus yang sangat panjang pada ikan herbivora merupakan kompensasi terhadap kondisi makanan yang memiliki kadar serat tinggi sehingga memerlukan pencernaan yang lebih lama. Pada organ Ikan Mas tidak ditemukan adanya lambung tetapi bagian depan usus halus yang terlihat membesar yang lebih dikenal dengan istilah "lambung palsu".

Sementara itu pemberian kombinasi pakan komersial dengan daun kangkung air pada perbandingan 1:1 (P2) dan 1:3 (P4) serta daun kangkung air 100\% (P5) memberikan pertumbuhan mutlak dan spesifik baik berat dan panjang Ikan Mas yang lebih rendah. Rendahnya pertumbuhan Ikan Mas pada perlakuan kombinasi 
pakan komersial dengan daun kangkung air pada perbandingan 1:1 (P2) diduga disebabkan karena jumlah pakan komersial yang diberikan terlebih dahulu lebih banyak dibandingkan perlakuan P3 sehingga Ikan Mas sudah terbiasa dengan pakan komersial tersebut dan akibatnya ikan menjadi tidak terlalu respon ketika diberikan daun kangkung air pada tahap berikutnya. Hal ini didukung oleh hasil pengamatan secara visual di lapangan, dimana masih ditemukan sisa pakan daun kangkung air yang tidak dimakan pada media pemeliharaan. Akibatnya ikan hanya mendapatkan nutrisi pakan dalam jumlah kecil sehingga pertumbuhan Ikan Mas menjadi kurang optimal. Penelitian ini sesuai dengan pernyataan Isnawati (2015), bahwa sebelum terjadinya pertumbuhan, kebutuhan energi untuk pemeliharaan harus dipenuhi terlebih dahulu. Sehingga apabila jumlah pakan yang tidak terpenuhi dan perbandingan yang tidak sesuai justru tidak dapat termanfaatkan secara optimal.

Pada perlakuan pemberian kombinasi pakan komersil dengan daun kangkung air pada perbadingan 1:3 (P4) dan perlakuan daun kangkung air 100\% (P5), ikan cepat beradaptasi dengan pakan daun kangkung air yang diberikan. Hal ini ditandai dengan tidak ditemukannya sisa pakan pada media pemeliharaan. Walaupun ikan cepat beradaptasi terhadap pakan daun kangkung air yang diberikan pada perlakuan P4 dan P5, namun pertumbuhan ikan saangat rendah. Hal tersebut diduga karena daun kangkung mengandung serat kasar yang cukup tinggi sehingga dapat menyebabkan pertumbuhan ikan yang tidak optimal apabila dikonsumsi secara berlebihan. Hasil penelitian ini sejalan dengan penelitian Pasha (2015) dan Haerudin et al., (2017), yang menyatakan bahwa kandungan serat kasar pada pakan akan mempengaruhi kecernaan total pakan. Dalam jumlah yang normal sebenarnya serat kasar sangat dibutuhkan untuk mempercepat eksresi sisa-sisa pakan melalui saluran pencernaan. Namun dalam jumlah yang berlebihan sangat tidak dianjurkan karena dapat menyebabkan bahan ini sulit dicerna dan dapat menurunkan komponen nutrisi yang dapat diserap oleh ikan. Menurut Habibi (2016), serat kasar merupakan bahan organik, bagian dari zat gizi karbohidrat yang tidak mudah larut dalam air. Serat kasar terdiri dari selulosa, hemisolulosa dan lignin yang Sebagian besar tidak dapat dicerna dan brsifat sebagai pengganjal.

Pemberian daun kangkung air sebagai pakan tambahan pada Ikan Mas dalam konsentrasi yang cukup tinggi, seperti pada perlakuan P3 masih bisa ditolerir oleh Ikan Mas disebabkan karena status fisiologis Ikan Mas tersebut, dalam hal ini adalah keberadaan organ lambung. Seperti diketahui bahwa Ikan Mas merupakan salah satu ikan herbivora yang memiliki lambung palsu, artinya bahwa Ikan Mas tergolong ikan tidak berlambung dan lambung palsu terbentuk karena bagian depan usus halus yang membesar. Menurut Megawati et al.,(2012), ikan tidak berlambung memiliki mikroflora didalam usus yang lebih banyak dibandingkan dengan ikan yang berlambung. Menurut Uthamy (2012), enzim merupakan katalisator biologis yang dihasilkan makhluk hidup untuk membantu proses biokima. Enzim yang banyak berperan dalam hidrolisis karbohidrat yaitu amilase seperti yang ditunjukkan Ikan Mas. Pada ikan herbivora, aktivitas enzim amilase lebih tinggi 
daripada enzim protease dan lipase. Keberadaan enzim dalam makanan akan meningkatkan daya cerna ikan terhadap bahan makanan.

Peningkatan pertumbuhan Ikan Mas yang lebih baik pada perlakuan pakan komersial 100\% (P1) dan perlakuan kombinasi pakan komersial dengan daun kangkung air pada perbandingan 1:2 (P3) juga didukung oleh nilai efesiensi pakannya, yaitu sebesar $14.70 \%$ untuk perlakuan P1 dan $13.57 \%$ untuk perlakuan P3 (Gambar 4). Namun secara keseluruhan semua perlakuan memberikan nilai efesiensi pakan yang kurang baik karena memiliki nilai efesiensi pakan yang lebih rendah dari 25\%. Menurut Haerudin et al., (2017), nilai efisiensi pakan yang baik yaitu lebih dari $25 \%$. Kondisi tersebut diduga karena waktu pengukuran panjang dan berat yang dilakukan setiap 7 hari sekali menyebabkan ikan rentan akan stress dan pakan yang diberikan banyak digunakan untuk mengadaptasikan diri daripada untuk pertumbuhan dan perkembangan. Menurut Febriansyah (2020), semakin tinggi nilai efisiensi pakan maka akan semakin tinggi pula laju pertumbuhan dari ikan, yang berpengaruh terhadap pertumbuhan ikan.

Sementara itu untuk nilai konversi pakan menunjukan bahwa perlakuan pakan komersial 100\% (P1) dan perlakuan kombinasi pakan komersial dengan daun kangkung air pada perbandingan 1:2 (P3) memberikan nilai konversi pakan yang baik, yaitu 6.84 untuk perlakuan P1 dan 7.37 untuk perlakuan P3 (Gambar 5). Menurut Putra (2017), nilai konversi pakan menunjukkan seberapa besar pakan yang dikonsumsi menjadi biomassa tubuh ikan, nilai konversi makanan pada ikan antara 1,5-8. Menurut Putri et al., (2012), nilai konversi pakan berkaitan erat dengan kualitas pakan yang diberikan, dimana semakin rendah nilai konversi pakan maka semakin baik kualitas pakan yang diberikan. Menurut Hamidi (2013), juga menjelaskan tingginya nilai konversi pada pakan berbahan limbah diduga karena pakan mengandung serat yang tinggi sehingga daya cerna nutrisi pada pakan menjadi rendah. Penurunan daya cerna protein ini disebabkan kemampuan ikan mencerna protein hanya sampai batas persentase tertentu, salah satu diantaranya bergantung pada kandungan serat kasar pada bahan pakan khususnya bahan nabati.

Semua perlakuan yang diberikan pada penelitian ini tidak mempengaruhi nilai kelangsungan hidup Ikan Mas, dimana rata-rata tingkat kelangsungan hidup Ikan Mas berkisar antara 97,50 - 100\%. (Tabel 1). Hal ini diduga karena didukung oleh kualitas air pemeliharaan yang masih berada pada kondisi yang masih sesuai untuk pemeliharaan Ikan Mas pada semua perlakuan yang diberikan tersebut (Tabel 2). Menurut Wulandari (2012), kisaran suhu optimal bagi kelangsungan hidup Ikan Mas yaitu pada suhu $25-30{ }^{\circ} \mathrm{C}$. Kisaran $\mathrm{pH}$ yang optimal bagi kelangsungan hidup Ikan Mas yaitu 6,5-8,5. Oksigen terlarut merupakan komponen penting bagi organisme perairan. Kisaran oksigen terlarut yang optimal bagi kelangsungan hidup Ikan Mas yaitu $<3 \mathrm{mg} / \mathrm{L}$. 


\section{Kesimpulan}

Berdasarkan hasil penelitian yang dilakukan dapat tarik kesimpulan bahwa penggunaan kombinasi pakan komersil dengan kangkung air sebagai pakan tambahan pada perbandingan yang berbeda dapat mempengaruhi pertumbuhan benih Ikan Mas (pertumbuhan berat mutlak, pertumbuhan panjang mutlak, laju pertumbuhn spesifik, efisiensi pemanfaatan pakan, dan konversi pakan) tetapi tidak mempengaruhi kelangsungan hidup. Perlakuan terbaik diperoleh pada perlakuan P1 (Pelet 100\%) akan tetapi memberikan pengaruh yang sama dengan kombinasi penggunan pakan buatan dengan daun kangkung air sebanyak 1:2 (P3).

\section{Daftar Pustaka}

Dinas Kelautan dan Perikanan. 2018. Potensi Usaha dan Peluang Investasi Kelautan dan Perikanan Provinsi Nusa Tenggara Barat.

Febriyansyah R. 2020. Pengaruh Penambahan Serbuk Daun Pepaya (Carica papaya L.) Pada Pakan Untuk Meningkatkan Pertumbuhan Ikan Mas (Cyprinus carpio). Skripsi. Universitas Mataram.

Habibi MBY. 2016. Potensi Penambahan Azolla sp. Dalam Formulasi Pakan Ikan Lele (Clarias sp.) Terhadap Nilai Kecernaan Serat Kasar dan Bahan Ekstrak Tanpa Nitrogen Menggunakan Teknik Pembedahan. Skripsi. Universitas Airlangga.

Haerudin, Zaenal A, Ayu AD. 2017. Tampilan Pertumbuhan Ikan Mas (Cyprinus carpio) yang Diberi Pakan Kombinasi Limbah Hasil Budidaya dan Pakan Komersil. Program Studi Budidaya Perairan, Universitas Mataram.

Hamidi. 2013. Pengaruh Jenis Pakan Segar yang Berbeda Terhadap Pertumbuhan Ikan Nila Gift (Orechromis niloticus). Skripsi. Universitas Teuku Umar.

Isnawati N. 2015. Potensi Serbuk Daun Pepaya Untuk Meningkatkan Efisiensi Pemanfaatan Pakan, Rasio Efisiensi Protein dan Laju Pertumbuhan Relatif Pada Budidaya Ikan Nila (Oreochromis Niloticus). Jurnal Ilmiah Perikanan dan Kelautan. Vol 7 (2): 121-124.

Megawati RA, Muhammad A, Moch AA. 2012. Pemberian Pakan Dengan Kadar Serat Kasar yang Berbeda Terhadap Daya Cerna Pakan Pada Ikan Berlambung dan Ikan Tidak Berlambung. Jurnal Ilmiah Perikanan dan Kelautan. Vol 4(2): 187-192.

Putra R. 2017. Pengaruh Penambahan Pemberian Kangkung Air (Ipomoea aquatica) Pada Pakan Terhadap Pertumbuhan Panjang dan Bobot Ikan Nila (Oreochromis niloticus). Skripsi. Universitas Sumatera Utara.

Putri AK, Zahidah, Syawaludin AH. 2016. Peningkatan Produksi Ikan Mas (Cyprinus carpio) Menggunakan Sistem Budidaya Polikuktur Bersama Ikan Nilem (Osteochilus hasselti) Di Waduk Cirata, Jawa Barat. Jurnal Perikanan Kalautan. Vol 7(1): 146-156.

Putri FS, Zahidah H, Kiki H. 2012. Pengaruh Pemberian Bakteri Probitoik Pada Pelet yang Mengandung Kaliandra (Calliandracalothyrsus) Terhadap 
Pertumbuhan Benih Ikan Nila (Orechromis niloticus). Jurnal Perikanan dan Kelautan. Vol 3(4): 283-291.

Uthamy CP. 2012. Pengaruh Substitusi Telur Ayam Pada Pakan Terhadap Laju Pertumbuhan Ikan Mas (Cyprinus carpio,L.). Skripsi. Universitas Negeri Yogyakarta.

Wulandari LEC. 2012. Pengaruh Pemberian Pakan Beryodium Terhadap Pertumbuhan Dan Kandungan Yodium Benih Ikan Mas (Cyprinus carpio). Skripsi. Universitas Airlangga.

Yanuar V. 2017. Pengaruh Pemberian Jenis Pakan yang Berbeda Terhadap Laju Pertumbuhan Benih Ikan Nila (Oreochromis niloticus) dan Kualitas Air di Akuarium Pemeliharaan. Ziraa'ah. Vol 42(2): 91-99.

Yunaidi, Anugrah, P. R., Ari, W. 2019. Aplikasi Pakan Pelet Buatan Untuk Peningkatan Produktivitas Budidaya Ikan Air Tawar Di Desa Jerukagung Srumbung Magelang. Jurnal Pemberdayan: Publikasi Hasil Pengabdian Kepada Masyarakat. Vol 3(1) 45-54. 